\title{
Distribution patterns of bomb tritium, chloride, sulphate, oxygen -18 and deuterium, in two shallow sand aquifers
}

\author{
Boniface C. E. Egboka \\ Department of Geology, University of Nigeria, Nsukka, Nigeria
}

(Received April 13, 1981: Accepted August 28, 1981)

\begin{abstract}
Detailed distribution patterns of bomb tritium $\left({ }^{3} \mathrm{H}\right)$, chloride $\left(\mathrm{Cl}^{-}\right)$, sulphate $\left(\mathrm{SO}_{4}^{2-}\right)$, oxygen-18 $\left({ }^{18} \mathrm{O}\right)$, and deuterium $\left({ }^{2} \mathrm{H}\right)$ are described for two unconfined shallow sand aquifers at Canadian Forces Base (CFB), Borden, Ontario, and Whiteshell Nuclear Research Establishment (WNRE), Pinawa, Manitoba, both in Canada. The study areas were highly instrumented with groundwater monitoring and sampling devices consisting of multilevel samplers and bundle piezometers. Groundwater samples were collected regularly and seasonally, and analysed for the isotopes $\left({ }^{3} \mathrm{H},{ }^{18} \mathrm{O}\right.$ and $\left.{ }^{2} \mathrm{H}\right)$ and the dissolved geochemical constituents $\left(\mathrm{Cl}^{-}\right.$and $\left.\mathrm{SO}_{4}^{2-}\right)$. The samples were collected at several depths within the aquifers and along various directions.

The geochemical parameters were interpreted in relation to the groundwater movement. Bomb ${ }^{3} \mathrm{H}$ showed two concentration patterns indicating two groundwater age-zones. An upper tritiated zone reflects young water recharged since the beginning of nuclear tests in 1953. The lower untritiated old water indicated water recharged before 1953. Thus, the recharge and discharge areas were established, and groundwater velocity and hydraulic conductivity were calculated for the description of the groundwater flow. The chloride and sulphate patterns were used to delineate the areal extent of the leachate plume in the aquifer beneath an abandoned landfill at CFB Borden. The sulphate concentrations at WNRE aquifer indicated two possible sources of groundwater recharge. The ${ }^{18} \mathrm{O}$ data for the Borden aquifer suggested that isotopic fractionation was occurring in the landfill so that ${ }^{18} \mathrm{O}$ enrichment was observed within the leachate plume. The ${ }^{18} \mathrm{O}$ and ${ }^{2} \mathrm{H}$ data from WNRE aquifer showed that an evaporative effect on the recharged groundwater was evident, resulting in slight enrichment in ${ }^{18} \mathrm{O}$ and ${ }^{2} \mathrm{H}$ as reflected by the seasonal fluctuations on recharge.
\end{abstract}

\section{INTRODUCTION}

Radioactive isotopes such as bomb tritium $\left({ }^{3} \mathrm{H}\right)$, dissolved geochemical constituents such as chloride $\left(\mathrm{Cl}^{-}\right)$and sulphate $\left(\mathrm{SO}_{4}^{2-}\right)$ and stable isotopes such as oxygen-18 $\left({ }^{18} \mathrm{O}\right)$ and deuterium $\left({ }^{2} \mathrm{H}\right)$, are very useful in the investigations of problems posed by contaminants or pollutants in the hydrologic systems. In integrated environmental tracing, they serve as very useful hydrologic indicators. Environmental tracing techniques in groundwater studies involve these naturally-occurring tracers present in the environment to monitor directions and rates of groundwater flow, and to investigate effects of groundwater movement on the distributions and transport of the geochemical con- stituents.

In the application and interpretation of these tracers in groundwater studies, accurate input functions for each geochemical parameter must be established. This enables an accurate monitoring of the concentration-distribution patterns of each parameter in the groundwater flow system with respect to distance and time of travel. As the dissolved constituent is transported, it may be subjected to the effects of hydrodynamic dispersion and advection which are the physical processes that control solute migration and dilute the input concentrations in groundwater flow systems. The loss or gain of solute concentration may also occur through chemical or biochemical reactions.

Since the beginning of atmospheric nuclear 
tests in 1953, precipitation has contained high concentrations of bomb ${ }^{3} \mathrm{H}$ that have been higher than those in precipitation prior to 1953. The "tritium unit" is used to express ${ }^{3} \mathrm{H}$ concentrations in hydrologic studies. One tritium unit (1 TU) is equal to one ${ }^{3} \mathrm{H}$ atom in $10^{18}$ hydrogen $\left({ }^{1} \mathrm{H}\right)$ atoms. The tritium content of precipitation before 1953 was estimated to be about 5 to $10 \mathrm{TU}$. The half-life of ${ }^{3} \mathrm{H}$ is 12.3 years so that the water that originated prior to 1953 contains ${ }^{3} \mathrm{H}$ concentrations much lower than 5 TU. During the thermonuclear tests, ${ }^{3} \mathrm{H}$ concentrations in precipitations in the northern hemispheres increased to hundreds and thousands of TU's. Atmospheric circulation has resulted in the rapid spread of bomb ${ }^{3} \mathrm{H}$ which occurs as fallout on a global scale.

The principal stable isotopes of water molecule used in hydrologic tracing studies are oxygen-18 $\left({ }^{18} \mathrm{O}\right)$ and deuterium $\left({ }^{2} \mathrm{H}\right)$. The differences in isotopic ratios of ${ }^{18} \mathrm{O} /{ }^{16} \mathrm{O}$ and ${ }^{2} \mathrm{H} /{ }^{1} \mathrm{H}$ are used in the study of groundwater flow, recharge and discharge. The ratios are expressed in delta units as permille differences related to an arbitrary standard SMOW (Standard Mean Ocean Water).

Sulphate is an effective groundwater tracer, but less useful than chloride and bomb ${ }^{3} \mathrm{H}$ because it may become chemically reactive when transported along the groundwater flow system. Under anaerobic conditions, $\mathrm{SO}_{4}^{2-}$ may be reduced and, thereby, lost from the flow system.
Sources of $\mathrm{SO}_{4}^{2-}$ contamination include acidrain-affected areas, landfills, sewage lagoons and fertilized agricultural areas.

\section{Study Areas, Sampling Methods AND LABORATORY ANALYSES}

Two unconfined sandy aquifers in Canada were investigated in great details. The aquifer below an abandoned landfill at Canadian Forces Base (CFB) Borden, Ontario, and another in a recharge zone at Whiteshell Nuclear Research Establishments (WNRE) Pinawa, Manitoba. The strata at CFB Borden consist of a uniformlygraded fine to medium sand, a silty fine sand and a lower silt unit (Fig. 1). The aquifer at WNRE Pinawa is unconfined in the recharge area but becomes semi-confined some distance away on both directions (Fig. 2).

As shown in Fig. 1, the regional direction of groundwater flow is predominantly horizontal, and northwards away from the landfill. Beneath the landfill, a downward vertical gradient exists, particularly in the months of March and April during the peak periods of spring recharge. The subsequent higher hydraulic head results in the inter-section of the basal part of the landfill by the water table. This enhances the pulse-like loading of the leachate into the groundwater flow system. At WNRE Pinawa, the water that recharged the aquifer from precipitation flows downwards and also laterally. A flownet analysis

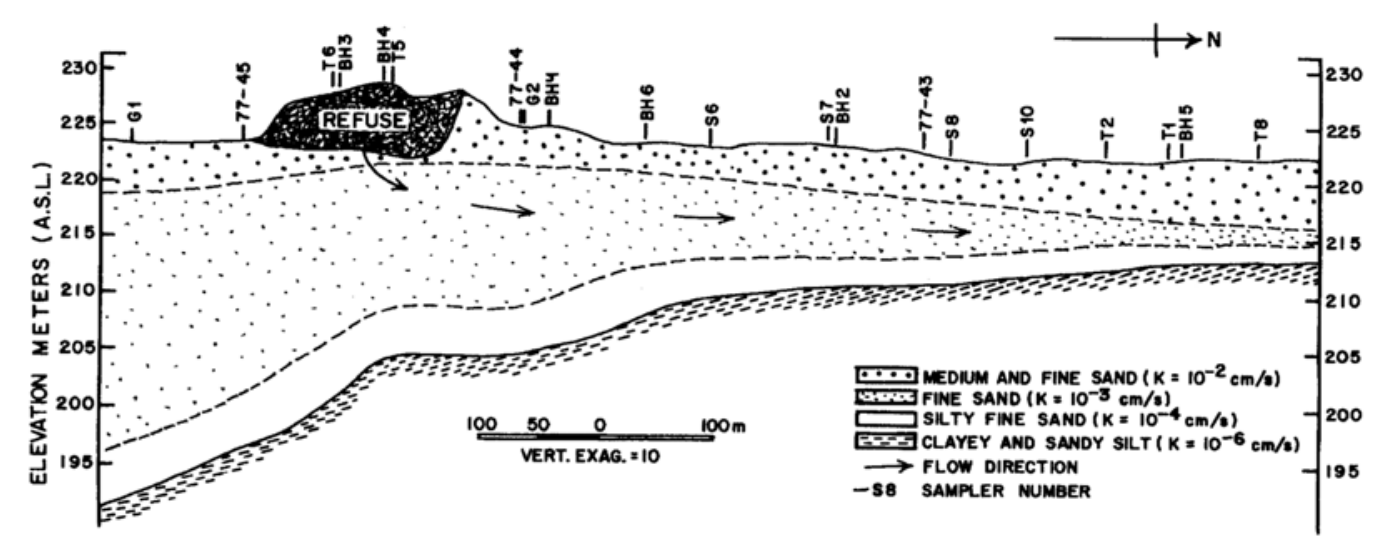

Fig. 1. The stratigraphy of CFB Borden aquifer (MACFARLANE et al., 1980). 
of seasonal waterlevel data collected from the monitoring network in the study area consistently indicated a zone of anomalously upward groundwater flow from the bedrock zone as shown in Fig. 2.

The monitoring and sampling network comprise multilevel samples (PICKENS et al., 1978) and bundle piezometers (EGBOKA, 1980 and MACFARLANE et al., 1980). These were installed at various localised depths in the groundwater flow systems, and at many locations to enable the establishment of well-defined boundaries of the isotopes and dissolved geochemical constituents. The groundwater samples were collected from small diameter tubes of the sampling network with small intake zones such that little or negligible mixing occurs between waters at different zones in the aquifer. The older method of monitoring and sampling for geochemical parameters by the use of pumping wells, observation wells and piezometers with large intake zones was not used because groundwater mixing occurs. Results from such samples when analysed may be erroneous and possibly lead to misleading interpretations.

Groundwater samples were collected mainly in the spring and summer of 1979, and a few additional ones were finally obtained in the spring of 1980. Approximately $250{ }^{3} \mathrm{H}$ samples from CFB Borden aquifer were analysed at the Environmental Isotope Laboratory of the Department of Earth Sciences, at the University of Waterloo, Ontario, Canada. About 200 samples from WNRE Pinawa were analysed at Chalk River Nuclear Research Laboratories (CNRL), Chalk River, Ontario, Canada. Twelve $\mathrm{ml}$ of groundwater sample and $15 \mathrm{ml}$ of Instagel emulsifier formed the standard. The limits of detection and precision of determinations in the laboratory at CRNL are $15 \mathrm{TU}$ and $\pm 10 \mathrm{TU}$, respectively, while at Waterloo they are $10 \mathrm{TU}$ and $\pm 10 \mathrm{TU}$, respectively. This reported precision depends only on counting statistical considerations. However, variations in vial thickness, vial background counts as a result of cap fluorescence, and small variations in preparation techniques result in an overall precision of about $\pm 15 \mathrm{TU}$, and sometimes may be as high as \pm 20

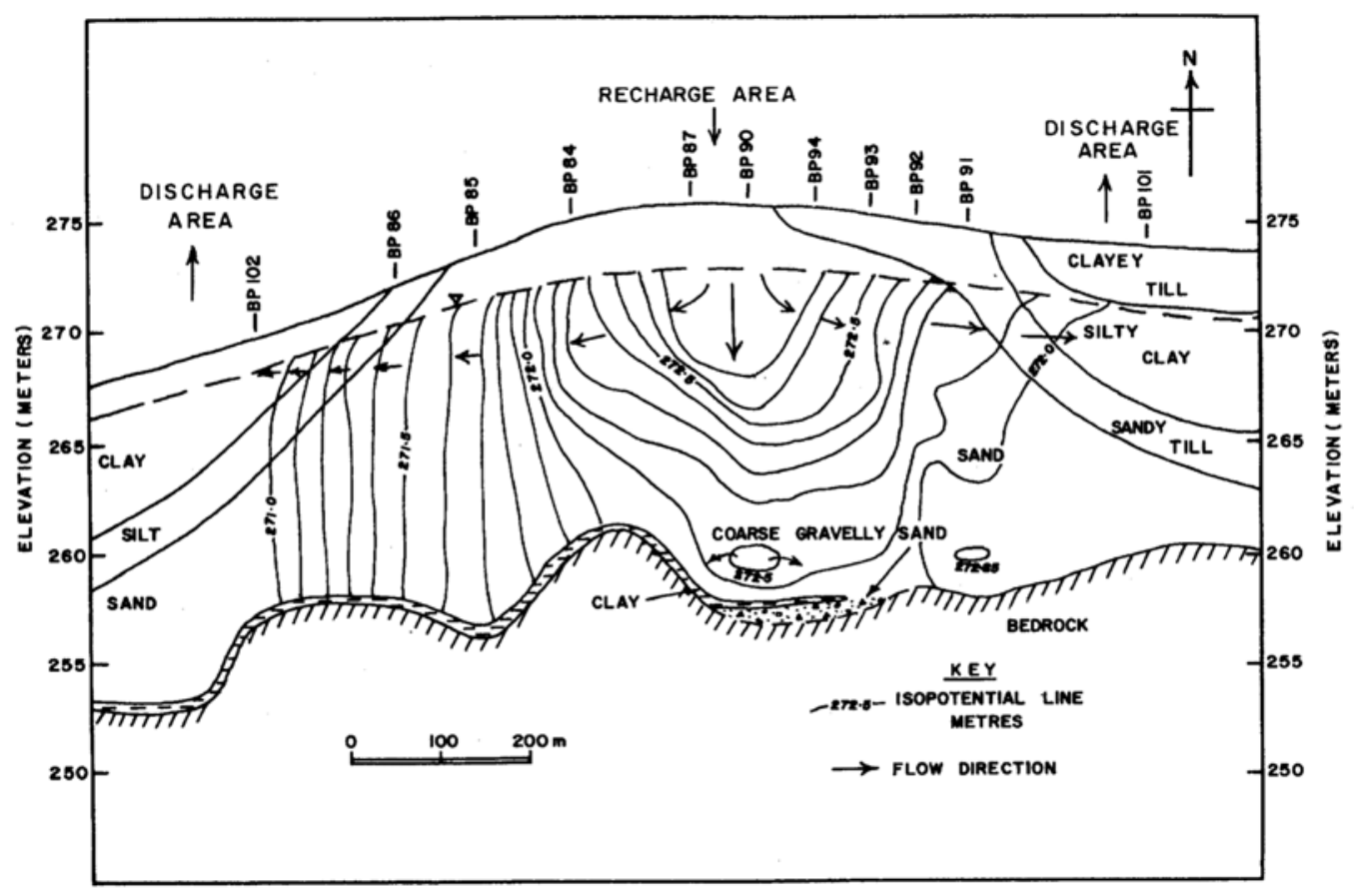

Fig. 2. The stratigraphy and isopotential lines at WNRE Pinawa aquifer. 
TU, if radiation-emitting solar events occur during the week the samples were counted. Thus, samples reported as negative values or as positive values less than $15 \mathrm{TU}$ are regarded as containing no detectable amount of bomb ${ }^{3} \mathrm{H}$.

Oxygen-18 and deuterium were determined using a VG Micromass 6O2D Mass Spectrometer. The ${ }^{18} \mathrm{O}$ and ${ }^{2} \mathrm{H}$ were analysed on carbon dioxide and hydrogen gas, respectively, and the results were expressed with respect to Standard Mean Ocean Water (SMOW) in the conventional $\delta$ - per mil notation $(\delta \%$ ) where:

$$
\delta \% \text { samples }=\frac{\mathbf{R}_{\text {sample }}-\mathrm{R}_{\text {standard }}}{\mathrm{R}_{\text {standard }}} \times 10^{3}
$$

$$
\text { and } \left.\mathrm{R}={ }^{2} \mathrm{H} /{ }^{1} \mathrm{H} \text { (or } \mathrm{D} / \mathrm{H}\right) \text {, or }{ }^{18} \mathrm{O} /{ }^{16} \mathrm{O}
$$

The precision of the analyses for both ${ }^{18} \mathrm{O}$ and ${ }^{2} \mathrm{H}$ are $\pm 0.15 \%$ o and $\pm 2 \%$, respectively.

The chloride and sulphate analyses were done with Dionex ion chromatography on acidified samples. The error attached to the chloride data varied between \pm 0.05 to $\pm 0.5 \mathrm{mg} /$ 1 , while that for sulphate ranged from \pm 0.3 to $\pm 1.0 \mathrm{mg} / 1$.

\section{AQUifer Parameters AND Flow NeT ANALYSIS}

Aquifer parameters An aquifer may be described as a water-saturated geologic unit or formation that may be exploited for water for economic use. The aquifer parameters of hydraulic conductivity $(\mathrm{K})$ and the actual linear groundwater velocity (Va) were calculated and used to describe the distributions and migrations of the dissolved geochemical constituents in the two shallow sand aquifers. The calculations were carried out using the principles of Darcy's Law (FREEZE and CHERry, 1979).

The hydraulic gradient (i) was obtained from the measurements of groundwater levels that gave the difference in hydraulic heads (dh), and from the distances between the measured wells $(\mathrm{dx})$. Using the slug test method of
Hvorslev (1951), and the conventional pumping test analysis (FrEEze and CHERRY, 1979), the average hydraulic conductivity values were determined. The saturated $\mathrm{K}$ is a measure of the ease with which a saturated soil unit is able to transport fluid, and is a property of both the water and the porous medium. By multiplying $\mathrm{K}$ with the hydraulic gradient, the specific discharge which is also called the Darcy velocity or the Darcy flux (Vd) is obtained thus:

$$
\mathrm{Vd}=\mathrm{K} \frac{\mathrm{dh}}{\mathrm{dx}}=\mathrm{Ki}\left(\mathrm{m}^{3} / \mathrm{m}^{2} / \mathrm{Yr}\right)
$$

The Darcy velocity is a macroscopic concept that leads to the measurement of average hydraulic values in the porous media. It is an apparent velocity. The actual groundwater velocity $(\mathrm{Va})$ is the intergranular microscopic flow that describes the velocity through the actual pore spaces of the soil skeleton, and is obtained thus:

$$
\mathrm{Va}=\frac{\mathrm{Ki}}{\mathrm{n}}=\frac{\mathrm{Vd}}{\mathrm{n}}(\mathrm{m} / \mathrm{Yr})
$$

where $\mathrm{n}$ is the porosity of the aquifer.

In addition to Va calculated using the measured $\mathrm{i}$ values and the $\mathrm{K}$ from the slug test and pumping test data, average velocity values were also obtained by dividing the total travel distance $(x)$ between the water table and the bomb tritium front that entered the flow system since 1953 by the number of years $(t)$ of travel (1953 -1978). The chloride front at the Borden landfill was used similarly to calculate the velocity since leachate-loading into the aquifer began in about 1940 to cover thirty-eight years of travel time (1940-1978), that is

$$
\mathrm{Va}=\frac{\mathrm{x}}{\mathrm{t}}(\mathrm{m} / \mathrm{Yr})
$$

Flow net analysis The water table wells, the piezometer nests, and the bundle piezometers were measured for water levels, and the data plotted on a two-dimensional cross-section to construct the hydraulic head distributions. 
The resulting set of isopotential lines and flowlines which must intersect at right angles forms a flow net. Figure 2 shows the equipotential or isopotential lines mainly, since it was possible to establish them with the measured hydraulic head data. As a result of the complex and curvilinear nature of the flowlines, only flow directions were indicated. Thus, groundwater flows occur from zones of higher potentials to lower ones.

The aquifer (Fig. 2) shows a shallow water table that forms a gentle mound on the groundwater regime. It is unconfined under the groundwater divide but becomes semi-confined some distance away in both directions. Beneath the groundwater divide, the bedrock topography suggests the presence of a burried channel with a semi-confined coarse gravelly layer above from where an upward component of groundwater flow occurs. The water which percolates into the aquifer from precipitation in the recharge area flows downwards and laterally until it reaches the discharge area where it occurs as effluent seepages.

\section{RESULTS AND DISCUSSION}

The detailed distribution patterns of the isotopes and the dissolved geochemical constituents in the two sand aquifers were used to study the groundwater movements of the two flow systems. The patterns of ${ }^{3} \mathrm{H}$ in ground- water were used to identify young waters, establish recharge and discharge zones, calculate residence times and groundwater velocity. Oxygen-18 and ${ }^{2} \mathrm{H}$ were used to study the evaporative and fractionation effects on the recharged water. Chloride and $\mathrm{SO}_{4}^{2-}$ were used to map the areal extent of the leachate plume at the Borden aquifer.

Camp Borden aquifer The ${ }^{3} \mathrm{H}$ distribution pattern along a regional cross-section of the aquifer is shown on Fig. 3. Two main ${ }^{3} \mathrm{H}$ concentration zones indicate two groundwater agezones. The upper zone contains high ${ }^{3} \mathrm{H}$ values that signify young waters recharged during and after the thermonuclear tests that started from 1953. The lower zone contains older water that entered the flow system before 1953, hence, the low ${ }^{3} \mathrm{H}$ values were recorded. Upgradient from the landfill in the southward direction, the bomb ${ }^{3} \mathrm{H}$ penetration is shallower while immediately beneath the landfill, the penetration is deeper. The deep ${ }^{3} \mathrm{H}$ penetration is due to the rise in hydraulic head below the landfill during the peak recharge period which causes water table mounding and hence a higher downward component of flow that drives the leachate deeper into the aquifer. Beneath the landfill, a thin zone of untritiated water exists along the bottom of the aquifer and at some distance downgradient of the landfill in the northward direction. However, at the northern end of the

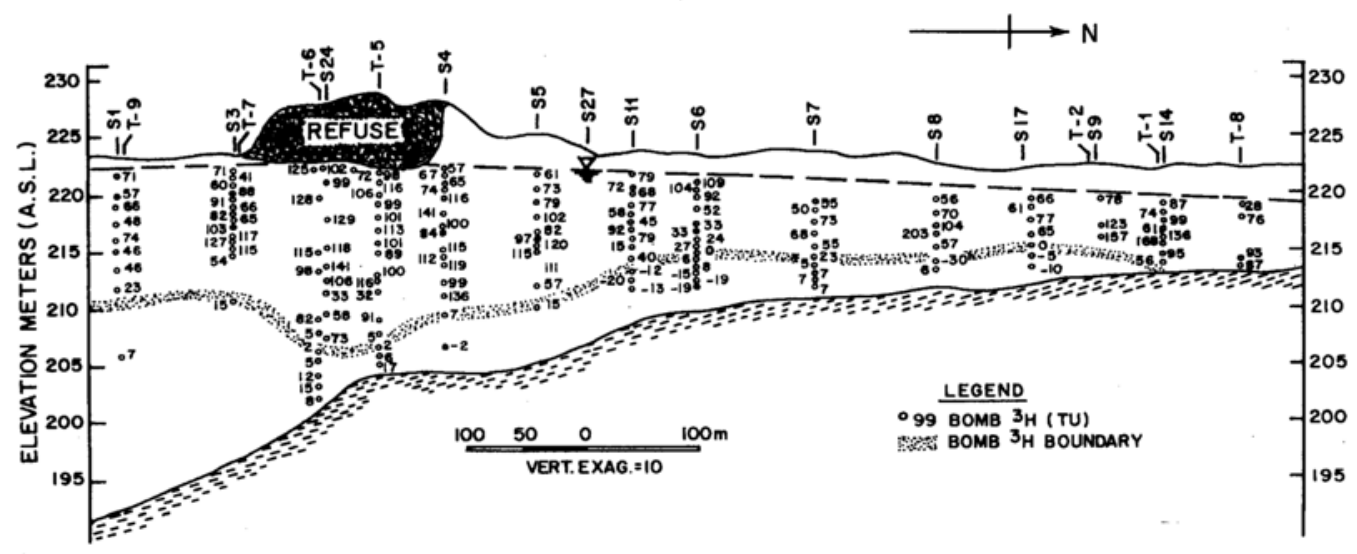

Fig. 3. Distribution patterns for ${ }^{3} \mathrm{H}$ in groundwater at CFB Borden. 
cross-section, the entire aquifer becomes tritiated. A comparison of the geological crosssection (Fig. 1) and Fig. 3 suggests that the upper boundary of the zone of untritiated water follows the silty fine sand unit, and that the untritiated water also occurs in a thin zone above the silty fine sand.

The chloride and sulphate distribution patterns are displayed in Figs. $4 \mathrm{a}$ and $4 \mathrm{~b}$, respectively. The high concentration values indicate that the $\mathrm{Cl}^{-}$and $\mathrm{SO}_{4}^{2-}$ originated from the landfill and they show the extent of distribution of the landfill-derived leachate plume. Near the front of the contaminant plume, $\mathrm{Cl}^{-}$could not be used conclusively as a definitive indicator of leachate contamination because of the influence of salt applied on a nearby road for deicing during the winter. Therefore, the existence of the frontal zone of the leachate plume delineated on the $\mathrm{Cl}^{-}$diagram was confirmed by the pattern of $\mathrm{SO}_{4}^{2-}$ distribution.

The boundaries between the tritiated and untritiated zones of the aquifer superimposed on the cross-sectional distributions of $\mathrm{Cl}^{-}$and $\mathrm{SO}_{4}^{2-}$ are also shown on Figs. $4 \mathrm{a}$ and $4 \mathrm{~b}$. The frontal segment of the leachate plume of $\mathrm{Cl}^{-}$ contamination from the landfill occurs almost entirely within the zone of non-tritiated water that originated from the landfill. Towards the landfill, the upper part of the plume is in the tritiated zone while the lower part is in the un- tritiated zone. The occurrence of the leachate plume front ahead of the bomb ${ }^{3} \mathrm{H}$ front that emanated from the landfill was expected because landfilling activity began in 1940, and bomb ${ }^{3} \mathrm{H}$ input started in 1953. Thus, the $\mathrm{Cl}^{-}$ or $\mathrm{SO}_{4}^{2-}$ front entered the groundwater flow system thirteen years before bomb ${ }^{3} \mathrm{H}$. Using the distances and times of travel for ${ }^{3} \mathrm{H}$ and $\mathrm{Cl}^{-}$ (EgBoKA, 1980), the groundwater velocity (V) and hydraulic conductivity $(\mathrm{K})$ were calculated. The bomb ${ }^{3} \mathrm{H}$ method gave a V of $12.3 \mathrm{~m} / \mathrm{Yr}$ and $\mathrm{K}$ of $4.3 \times 10^{-3} \mathrm{~cm} / \mathrm{S}$; the chloride method gave $17.8 \mathrm{my} / \mathrm{yr}$. and $6.1 \times 10^{-3} \mathrm{~cm} / \mathrm{S}$ for $\mathrm{V}$ and $\mathrm{K}$, respectively.

The ${ }^{3} \mathrm{H}$ concentrations in precipitation at Ottawa, Canada, showed annual variations between 1953 and 1978 (IAEA Tech. Reps., 1953 to 1978). Ottawa has the longest record of bomb ${ }^{3} \mathrm{H}$ in the world, and is the nearest IAEA recording station to the study areas. High pulses of bomb ${ }^{3} \mathrm{H}$ were injected into the atmosphere particularly during the major tests of 1952 , 1954, 1958, 1961, 1962 and 1968. The largest number of tests (143) were conducted in 1962 while the second highest number of tests (96) were carried out in 1958 (CARTER and MOGHISSI, 1976). As a result of the effects of radioactive decay and hydrodynamic dispersion, the smaller and earlier ${ }^{3} \mathrm{H}$ pulses injected into the groundwater flow systems have been reduced significantly in aquifers. However, the largest ${ }^{3} \mathrm{H}$

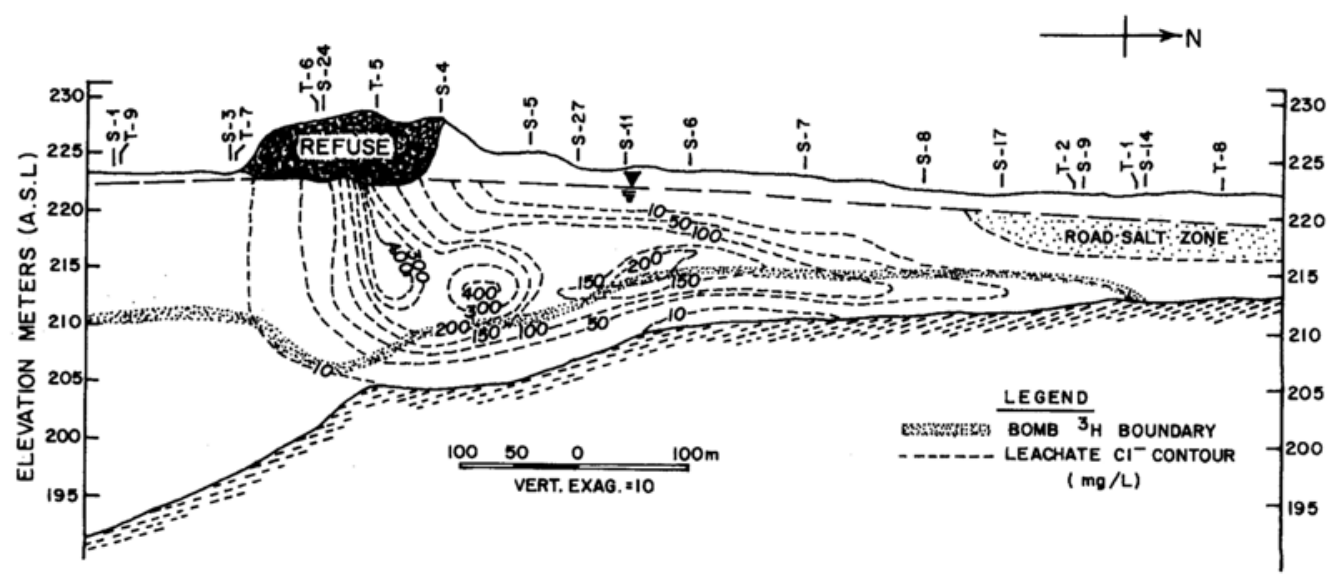

Fig. 4a. Distributions of $\mathrm{Cl}^{-}$with superimposed boundary between tritiated and non-tritiated groundwater. 


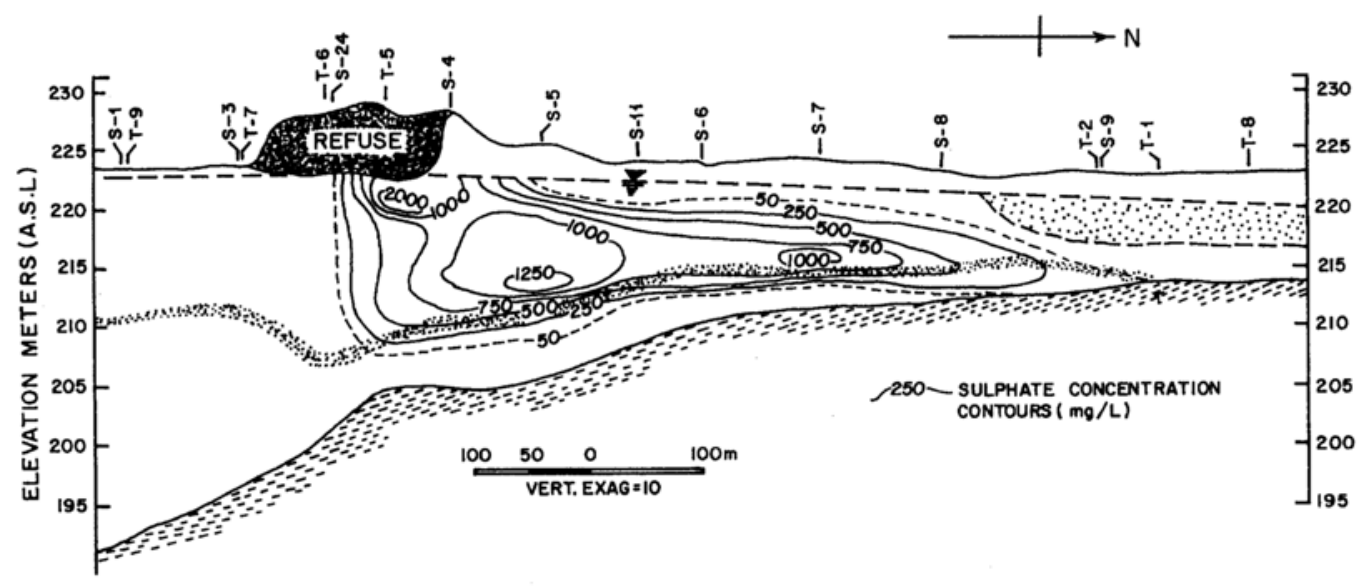

Fig. 4b. Distributions of $\mathrm{SO}_{4}^{2-}$ with superimposed boundary between tritiated and non-tritiated groundwater.

peaks covering the 1962 to 1968 inputs are still identifiable (Figs. 3 and 6) although the annual peaks have been lost owing to dispersion. The extent of spread of bomb ${ }^{3} \mathrm{H}$ in the cross-section also indicates considerable longitudinal migration and mixing, but an insignificant mixing in the lateral direction.

The oxygen-18 and deuterium distribution patterns are shown on Figs. 5a and 5b. Whereas ${ }^{2} \mathrm{H}$ distribution in the aquifer did not show significant variations, the ${ }^{18} \mathrm{O}$ within the leachate contaminated zone was enriched close to the landfill but did not vary significantly away from it. The ${ }^{18} \mathrm{O}$ enrichment was probably caused by a combination of factors within the environ- ment of the landfill. These factors may include biological fractionation of the refuse that tended to concentrate the heavier ${ }^{18} \mathrm{O}$ isotope, the heat energy probably released in the decomposition process might have increased the evaporation rate of the lighter ${ }^{16} \mathrm{O}$ isotope, thereby, concentrating the heavy one, also the composite organic matter deposited in the landfill might have been enriched in the heavy isotope in vivo before burial.

WNRE Pinawa The results of ${ }^{3} \mathrm{H}$ analysis of groundwater samples are given on Fig. 6. The bomb ${ }^{3} \mathrm{H}$ distribution patterns show two distinct groundwater age-zones: an upper zone that



Fig. Sa. Distribution patterns for ${ }^{18} \mathrm{O}$ in $\mathrm{CFB}$ Borden aquifer. 


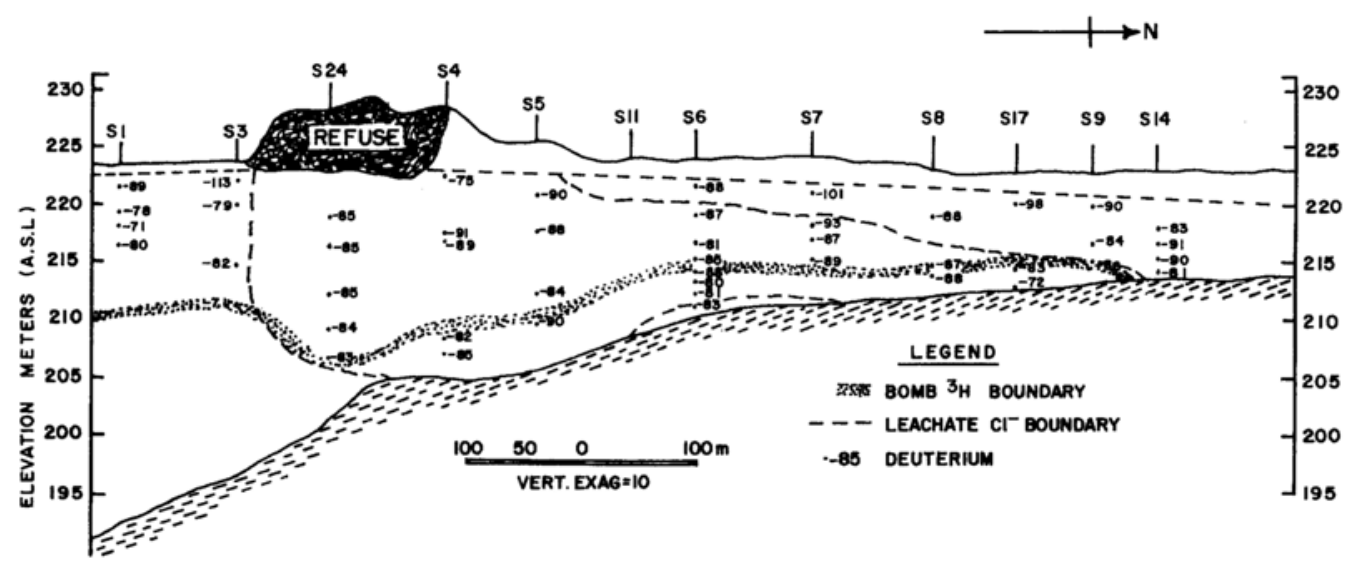

Fig. 5b. Distribution patterns for ${ }^{2} \mathrm{H}$ in groundwater at CFB Borden aquifer.

contains high ${ }^{3} \mathrm{H}$ values indicating young water that entered the flow system after 1953; a lower zone containing untritiated water. The boundary between the two age-zones represents a mixture of the two types of water. The ${ }^{3} \mathrm{H}$ distribution pattern is strongly related to the direction of groundwater flow in that bomb ${ }^{3} \mathrm{H}$ was present in the zones of the aquifer where modern or post-1953 water has penetrated while it was not measured in groundwater zones that has no modern water (Fig. 6).

In the recharge zone at the upland area, the ${ }^{3} \mathrm{H}$ values at the water table zone are similar to the present day values in precipitation that may occur between the range from 70 to $120 \mathrm{TU}$. In the horizontal and transitional flow domain in the westward direction, the ${ }^{3} \mathrm{H}$ concentrations are predominantly spread out in a range between

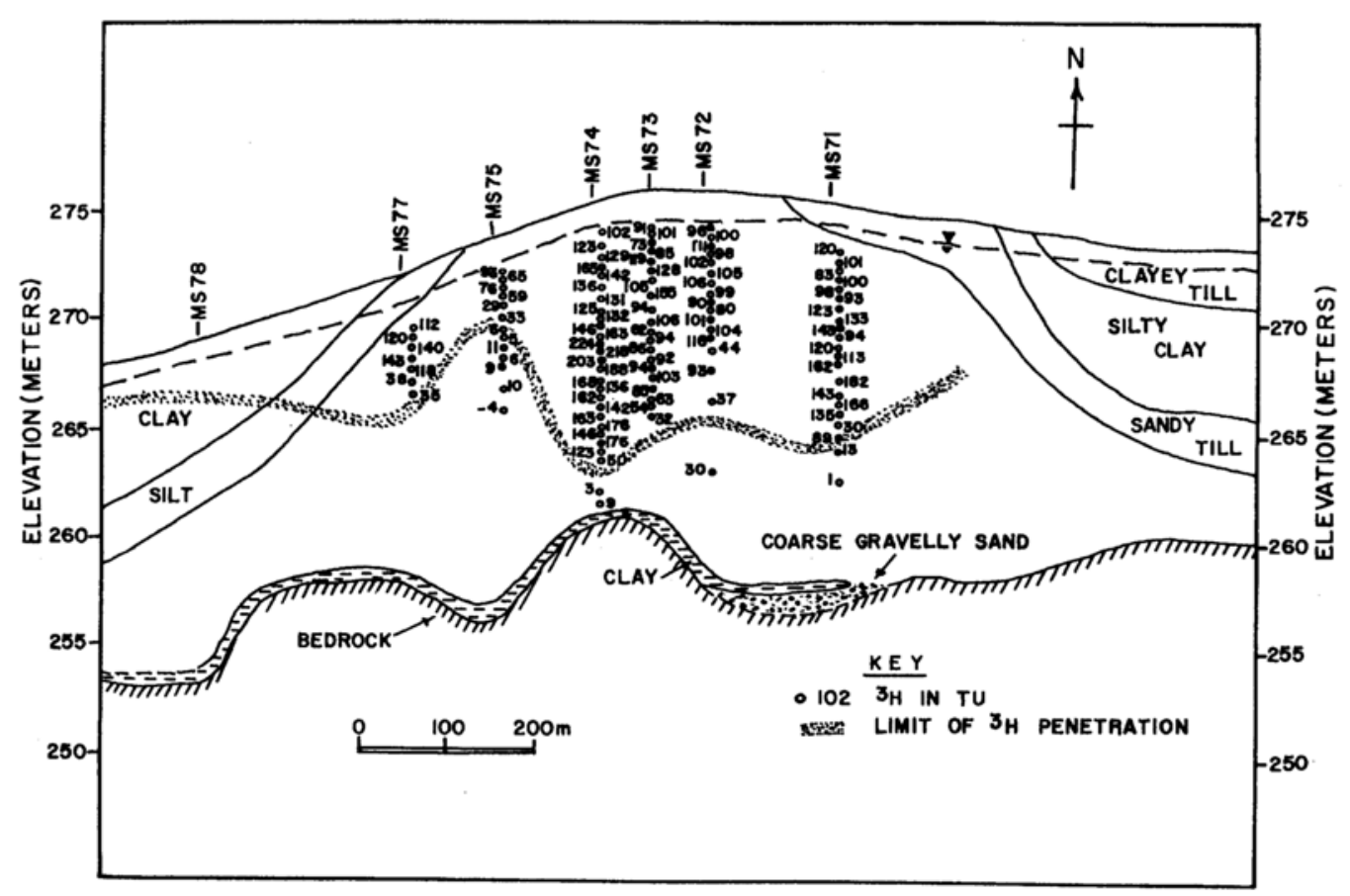

Fig. 6. Distribution patterns for ${ }^{3} \mathrm{H}$ in groundwater at WNRE aquifer. 
90 and $224 \mathrm{TU}$ horizontally and vertically. Towards the discharge area west of Fig. 6 where the aquifer is confined by the glaciolacustrine clay and silt, low ${ }^{3} \mathrm{H}$ occurred. Close to the bedrock, an upward component of flow was established from a flownet analysis. This flow which appeared to be old water of pre-1953 origin possibly prevented the post-1953 tritiated water recharged from above from getting to the aquifer zone close to the bedrock. The velocity and hydraulic conductivity estimated with bomb ${ }^{3} \mathrm{H}$ method are $15.8 \mathrm{~m} / \mathrm{yr}$ and $1.4 \times 10^{-3} \mathrm{~cm} / \mathrm{S}$.

The chloride patterns at WNRE aquifer did not show significant variations but $\mathrm{SO}_{4}^{2-}$ coincided with the tritiated section of the aquifer while the untritiated part had low to insignificant concentrations of $\mathrm{SO}_{4}^{2-}$. The upward flowing older water had no bomb ${ }^{3} \mathrm{H}$ and $\mathrm{SO}_{4}^{2-}$ while the overlying young water had high bomb ${ }^{3} \mathrm{H}$ and high $\mathrm{SO}_{4}^{2-}$, thereby, identifying two possible sources of groundwater recharge.

The distribution patterns for ${ }^{18} \mathrm{O}$ and ${ }^{2} \mathrm{H}$ are shown on Fig. 7. Both isotopes showed slight variations along the flow directions from the recharge to the discharge areas. High and low values for both isotopes are exhibited eastwards. The detailed instrumentation and sampling network made it possible to notice the significance of the small variabilities that may be a reflection of the seasonal climatic effects on the recharge water. The spring snowmelt water is enriched in the lighter isotopes $\left({ }^{16} \mathrm{O}\right.$ and $\left.{ }^{1} \mathrm{H}\right)$ such that water recharged during the period will have low ${ }^{18} \mathrm{O}$ and ${ }^{2} \mathrm{H}$. The water recharged during the hot periods of summer is enriched in the heavy isotopes $\left({ }^{18} \mathrm{O}\right.$ and $\left.{ }^{2} \mathrm{H}\right)$. This isotopic labelling of groundwaters aids the tracing of seasonal fluctuations along the flow system.

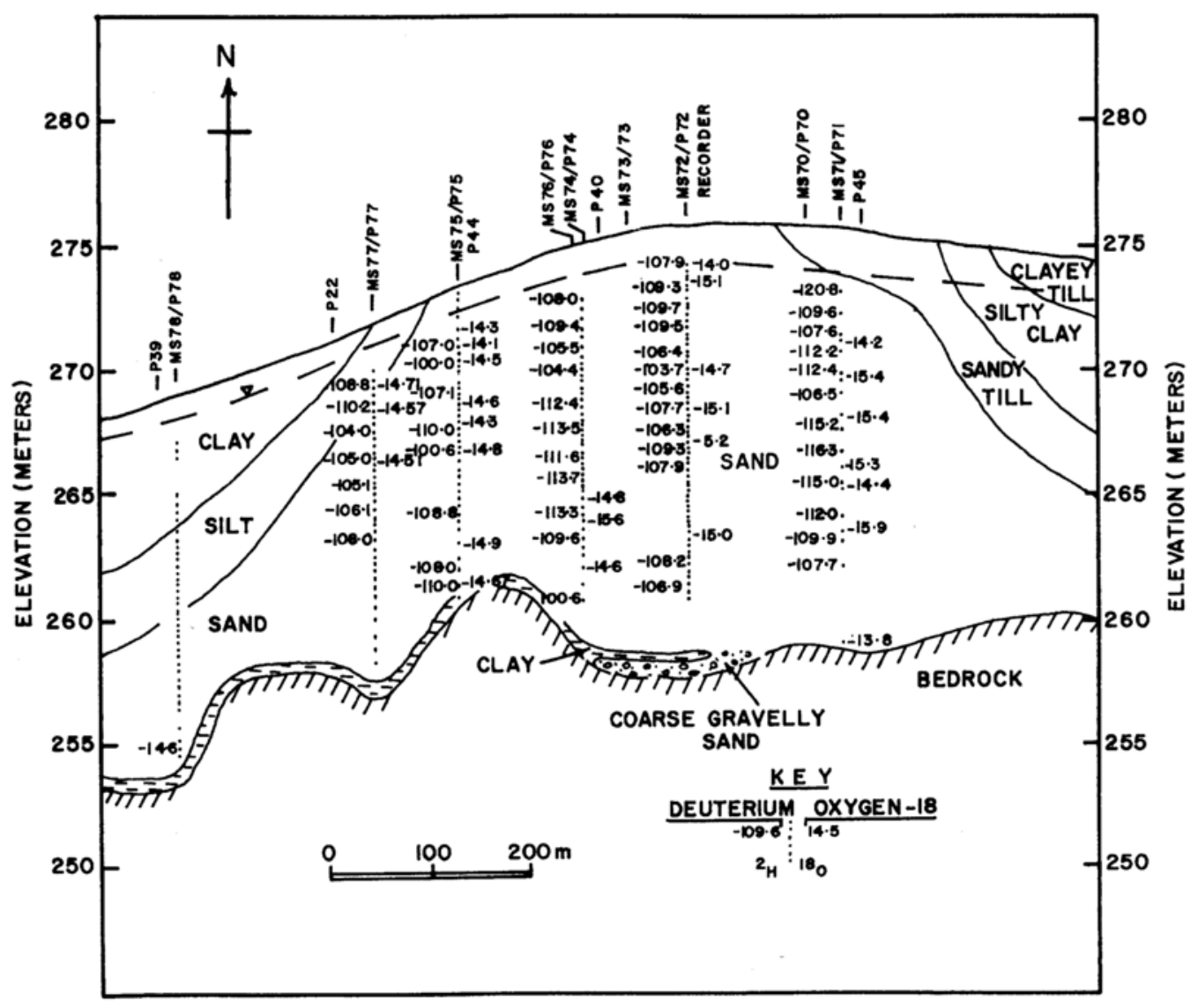

Fig. 7. Distribution patterns of ${ }^{18} \mathrm{O}$ and ${ }^{2} \mathrm{H}$ in groundwater at WNRE aquifer. 
Two questions on the distributions of oxygen-18 and deuterium at WNRE aquifer are very significant: Why significant variations on ${ }^{18} \mathrm{O}$ and ${ }^{2} \mathrm{H}$ cannot be observed along the northsouth direction of Fig. 7; and why the upwardflowing groundwater has the same ${ }^{18} \mathrm{O}$ and ${ }^{2} \mathrm{H}$ values as those of the overlying modern water. The slight variabilities in the concentrations of the stable isotopes introduced during recharge by the seasonal inputs were apparently obliterated by the predominant longitudinal dispersion and the small lateral mixing occurring during the downward transport. The overlying tritiated modern water has similar ${ }^{18} \mathrm{O}$ and ${ }^{2} \mathrm{H}$ values as the upward-flowing older water probably because the input sources may originate from the same watershed and might have been subjected to no major climatic changes that may cause isotopic fractionation which would have labelled the modern and old water differently.

Acknowledgements-The contributions made by ProfesSOIS JOHN A. CHERRY, ROBERT N. FARVOLDEN and PETER FRITZ, all of the Department of Earth Sciences, University of Waterloo, Waterloo, Ontario, Canada during the course of the investigations are acknowledged. Funds for the research were provided by the Canada Department of Environment, the Ontario (Canada) Lottery Fund, the National Science and Engineering Research Council Canada, and Whiteshell Nuclear Research Establishment Pinawa, Manitoba. The author also thanks Dr. K. M. ONUOHA and Dr. MIKE EZEPUE, both of the Department of Geology, University of Nigeria Nsukka, Nigeria for reviewing, Mr. ANTHONY NWIKE for typing the manuscript, and Mr. FOSTER OZOANI for drafting the figures.

\section{REFERENCES}

CARTER, M. W. and A. A. Moghissi (1976) Three decades of nuclear testing. Health Physics, Pergamon Press, No. 33, 55-71.

EGBOKA, B. C. E. (1980) Bomb tritium as an indicator of dispersion and recharge in shallow sand aquifers. Unpubl. Ph. D. thesis, University of Waterloo, Waterloo, Ontario, Canada, 190pp.

FreEZE, R. A. and J. A. ChERRY (1979) Groundmater. Prentice-Hall Inc., Englewood Cliffs, New Jersey $07632,604 p p$.

HVORSLEV, M. J. (1951) Time lag and soil permeability in groundwater observations. U.S. Army Corps Engrs. Waterways Exp. Sta. Bull. 36, Vicksburg, Miss.

International Atomic Energy Agency (IAEA) Tech. Rep. Series: Environmental isotope data Nos. 1 to 6 for years 1953 to 1975 .

MacFarlane, D. S., J. A.' CherRy, R. W. Gillham and E. A. SUDICKY (1980) Hydrogeological Studies of An Abandoned Landfill on a Sandy Aquifer: Physical Hydrogeology. Submitted to the Journal of Hydrology.

PiCKenS, J. F., J. A. Cherry, G. E. GrisaK, W. F. MERRITT, and B. A. Risto (1978) A multilevel device for groundwater sampling and piezometric monitoring. Groundwater, 16, 322-327. 